\title{
Mansonella ozzardi
}

National Cancer Institute

\section{Source}

National Cancer Institute. Mansonella ozzardi. NCI Thesaurus. Code C122326.

A species of parasitic nematodes in the family Onchocercidae. The lifecycle of M. ozzardi involves biting midges or blackflies and humans. Infestation causes serous cavity filariasis. 